\title{
From the Power of Local Authorities to Local Self- Government in Kosovo
}

\author{
Mr. Sc. Ramiz Fazliu \\ Lecturer of ILIRIA College, Law Faculty; Republic of Kosovo \\ ramizfazliu@hotmail.com
}

Doi:10.5901/ajis.2015.v4n1s2p145

\begin{abstract}
Local self-government as democratic achievement takes emphasised place on the new legal system of the Republic of Kosovo, which is based on the principles contained in the European Charter of Local Self-Government and other relevant international Conventions, the Constitution and laws of Kosovo, UNMIK Regulations, the President's Ahtisaari Comprehensive Plan and Agreement of Brussels. These are basic resources and legal basis for the organization and functioning of local self-government in Kosovo after the war until today organized at the municipal level. The system of local self-government during this period has passed through a continuous process of reform which is characterized by numerous challenges and major changes that have followed the general process of state-building in Kosovo.
\end{abstract}

Keywords: Power, Local Authorities, Local Self- Government, Kosovo

\section{The Power of Local Authorities in Kosovo $1999-2000$}

After the war and the liberation of Kosovo, Kosovo Provisional Government formed under the joint decision of all political parties military participating in the Rambouillet Conference, made the first attempts to start the normalization and institutionalization of life in Kosovo in central and local level.

In order to create a legal basis for the functioning of local government, the Provisional Government adopted Decree on Local Government, by which was determinate the ways of organization and functioning local authority in Kosovo. Under this Decree, municipalities constitute the basic territorial unit in which citizens realize common interests.

Decree provides unique system of local government functioning, but in practice the functioning failed to extend to all municipalities in Kosovo. For the organization of life in municipalities and for the decisions of citizen's interests, the Provisional Government, namely the Ministry of Local Government in order to cover the institutional vacuum appointed mayors and other holders of executive functions. These were therefore the only legitimate authorities during this period at the local level.

Thanks to the appointment and organization of local temporary structures, successfully were faced the emergency period and the return of the population that was violently removed from Kosovo, and the beginning of reconstruction of infrastructure in cooperation with international institutions and organizations.

The interim government, fulfilling its mission by obligations and created circumstances in Kosovo, ceases to exist along with all other structures in Kosovo at that time, then, which were not under the authority of Resolution 1244 of the UN.

All responsibilities of the organization and functioning of institutional life in Kosovo after this phase passed under the authority of UNMIK and joint administrative structures were established, like Interim Administrative Council (IAC) and the Transitional Administrative Council (TAC), under the authority of the Special Representative of the Secretary General (SRSG) of UN.

In this period was formed the Department of Local Administration within the UNMIK structure, which was led by two co-leaders, one of them was international and the other one local. The task of this department was organizing authorities and local administration in the existing municipalities, until the first local elections in Kosovo would be held in October 2000 , when the building of democratic elected institutions of Kosovo started at the local level.

\section{Local Administration 2000 - 2008}

With the establishment of UNMIK in Kosovo, in year 2000 were adopted two main regulations for the establishment and functioning of the new system of local Self-Government, respectively the Regulation 2000/43 was adopted for the names, 
numbers and boundaries of municipalities and the Regulation 2000/45 for Self-Government of Municipalities in Kosovo.

On 28 October 2000 the first local democratic elections were held and the Municipal Assemblies were constituted, Assemblies troops and was built administrative civil service. Municipalities, in this period the organization of local selfgovernment in Kosovo have been functioning based on UNMIK Regulation 2000/45.

Until the decision of Kosovo's future status, with this regulation in accordance with Resolution 1244 of the Security Council of the United Nations, provisional institutions for democratic and autonomous self-government at the municipal level were established, as a step in the progressive transfer of administrative responsibilities of Mission Interim Administration of United Nations in Kosovo (UNMIK), which will supervise and facilitate the consolidation of these institutions.

According the Regulation 2000/45, the basic territorial unit of local self-government in Kosovo is the municipality, which exercises all the power, which is not expressly reserved for the central government. Municipalities regulate and manage public affairs in their territory within the limits established by law, to ensure conditions for a peaceful and normal life for all inhabitants of Kosovo. Each municipality according the regulation has its own legal status, the right to own and manage property, the ability to sue and be sued in court, the right to contract and to hire workers.

With the Regulation 2000/45 were set taxably the powers of municipalities in Kosovo. Therefore, the municipalities within its territory and within the laws have the right to regulate any activity autonomously under their own responsibility and which do not conflict with the laws of Kosovo.

The central government can allow the municipality with additional competences within the scope of authority of the central government. Municipalities within their competences derive Municipal Statute and municipal regulations.

The first local elections of 28 October 2000 were proportional electoral system with open lists, while the mandate of the Municipal Assembly members was two (2) years.

The highest body of the municipality is the Assembly, which is elected directly and carries out the functions and responsibilities defined in Regulation 2000/45. The Assembly has also the Chairman elected by the composition of Parliament.

With this regulation is foreseen the possibility that the Municipal Assembly delegates the power to make decisions on other bodies of Assembly such as; Assembly Committees, Head of Municipal Assembly or Chief Executive Officer.

The Regulation 2000/45 has provided a degree of local autonomy, referring to the European Charter of Local SelfGovernment, which defines the rights and competences of local authorities, the European Convention for the Protection of Human Rights and Freedom, the European Charter for Regional languages or minorities and the Convention of the elimination of all forms of discrimination.

During this period, the Municipal Assemblies have functioned with limited autonomous capacities, because the reserved powers of UNMIK were exercised by the Municipal Administrator, who had executive power over the decisions of the Municipal Assembly and other administrative bodies.

The Constitutional framework of local self-government system is referred by only one paragraph in Chapter of the basic Provisions precisely in article 1. Paragraph 3., which determinates the level of organization at the local level and explicitly stated. "Kosovo is consists of municipalities, which are the basic territorial unit of local self-government with responsibilities stipulated by the legislation of UNMIK, which is in power, on local self-government and municipalities in Kosovo ".

The need to change the competences, organizational structure, responsibilities and electoral system, were summarized in UNMIK Regulation 2007/30, which almost prepares the municipal self-government in the spirit of the laws that will be approved in the Assembly of Kosovo based on Constitution and Comprehensive Package of President Ahtisaari.

The Regulation 2000/45, is amended by Regulation 2007/30, to adjust the changes mainly related to the direct election of mayors and defining three types of competencies such as: own, delegated and enhanced competencies.

The changes of the Regulation 2007/30, were related to the election of the mayor directly, unlike Regulation 2000/45, where the mayor was elected by the votes of elected representatives in the Municipal Assemblies. Now the Mayor takes also the executive role and appoints municipal Directors, who are political appointees and assist the mayor in carrying out its duties and responsibilities.

Own competences according the Regulation 2007/30 - the list of competencies in this regulation includes: local economic development, urban and rural planning, land use and development, implementation of building regulations and building control standards, environmental protection at the local level, supply and maintenance of public services and local emergency response. Such authority would be provided later in the future law on local self-government which was adopted after the declaration of independence and would be the same for all municipalities. 
Delegated Powers - This Regulation provides also the possibility of delegating the competences from central authorities to local authorities in some areas such as: cadastral records, civil records, voter's registration, business registration and licensing, distribution of social assistance payments (excluding pensions) and protection of forests.

Enhanced Competencies - It is anticipated that certain municipalities, where the Kosovo Serb minority community is in majority, to have enhanced municipal competencies in several areas: higher education, including registration and licensing of educational institutions, secondary medical care, including registration and licensing health institutions, recruitment, payment of salaries, training of health personnel and cultural issues, including the protection and promotion of cultural and religious heritage within its territory, participation to appoint the police station commanders.

The effects of the Regulation 2007/30, in organization and functioning of Local Self-government are in preparation of elected bodies for adaptation to the changes that would bring the Law on the Organization of Local Self-Government in Kosovo and other laws related the scope of Local Self-government based on Constitution of the Republic of Kosovo and the laws deriving from the President's Ahtisaari Comprehensive Package.

\section{Local Self- government in the President's Ahtisaari Comprehensive Proposal}

At the proposal of President Ahtisaari in third annex of this agreement, are described detailed tasks for the organization and responsibilities of Local Self-government bodies, taking into account the process of decentralization. In this annex are described and taken into accounts the concerns and worries of the Serbian minority community and other communities living in Kosovo.

To encourage and ensure active participation in public life of non-majority communities and to strengthen good governance and also to increase the efficiency and effectiveness of public services in the whole Kosovo, principles and provisions that are foreseen in this document, will also be incorporated with constitutional and legal provisions within positive Kosovo legislation.

The main principles of decentralization are defined within the constitution, as provided in Article 8 of Annex 1 of the Agreement where states: Kosovo will be consist from municipalities that will have a high degree of local self-government and which encourage and ensure an active participation of all citizens in democratic life.

This was perhaps a premise throughout the process of negotiations on the political status of Kosovo in Vienna, where a great attention has been made for the establishment of an advanced and sustainable Local Self-government on treatment for minorities in Kosovo.

This somehow was preceded by the report of the Council of Europe's Committee for decentralization in year 2003, which gave the first recommendations on how should be organized and decentralized the local government.

In year 2005, the special envoy of the UN Secretary General, Mr.. Kai Eide, has reported in regard of meeting the standards before the status focusing on the obligations of Kosovo institutions for the treatment of minority communities and in particular Serb minority community.

After negotiations started, the developments in process showed that the status of Kosovo, respectively the independence of Kosovo and the treatment of minorities in Kosovo and especially the Serb minority will have a solution "sui generis" (special type).

After nearly two years of negotiations and efforts to find a compromise between the negotiating delegations, UN special envoy to lead the negotiations for the status of Kosovo, presented his proposal to the UN General Secretary, which proposal was not taken in consideration in the UN Security Council warning because of Russia's veto, and this was the epilogue of the negotiations process without the possibility of reaching agreement.

According to this proposal, Kosovo shall enact new law on Local Self-government and other laws of Local Selfgovernment in order to strengthen the competences and organization of municipalities, as foreseen in the comprehensive plan of President Ahtisaari.

In all municipalities where responsibilities fall on the setup and management of public affairs the principle of subsidiarity should be respected. Based on this principle are determinate the own municipal competences, delegated competences and enhanced competencies.

The enhanced municipal competencies are valid only for a number of municipalities with a majority Serb community of the population, such as those in the field of higher education, culture and the cultural heritage and secondary healthcare. However, the rights and competences set also for local finances, in the area of inter-municipal cooperation, membership in associations, cooperation with institutions of local self-government in Serbia, the establishment of new municipalities and other issues of local self-government bodies functioning, present national and international obligation according the Constitution of the Republic of Kosovo, adopted in April 2008, and the laws coming 
out from the package of laws for the status of Kosovo, one of these is also the Law of local Self-Government in Kosovo (2008)

\section{Local Self-government within the Constitution of the Republic of Kosovo (2008)}

Local self-government is defined as a constitutional category also within the Constitution of the Republic of Kosovo, adopted on 8 April 2008, which entered into force on 15 June 2008.

In Chapter X of the Constitution, Articles 123 and 124 stipulate general principles, organization and functioning of local self-government.

The right of local self-government is guaranteed and regulated by law (Organic Law on Local Self-Government in Kosovo adopted in 2008) and it is exercised through representative bodies elected by general, equal, free and direct elections and secret vote.

The activity of local self-government is based on the Constitution and laws of the Republic of Kosovo in accordance with the European Charter of Local Self-Government.

The Local self-government is based on the principles of good governance, transparency, efficiency and effectiveness in offering of public services, paying particular attention to the specific needs and concerns of communities which are not majority and their members.

Basic unit of local self-government in the Republic of Kosovo is the municipalities. Municipalities have a high degree of local self-government and encourage and ensure active participation of all citizens in the decision making process of local authorities.

The establishment of municipalities, boundaries, competences and ways of its organization and functioning are regulated by law.

The Constitution also determinates the basic competencies, enhanced and delegated in accordance with the law. State authority, which delegates the competences, pays the costs for exercising delegated competences.

The organization and functioning of local self-government, the Constitution of the Republic of Kosovo has set in Article 124, paragraph 1, 2, 3 4, 5, 6, 7,27 and the laws enacted based on it.

As a result of these obligations came to The wellknown agreementof Brussels on 18 April 2013. This Agreement has sparked a lot of criticism and debate within intellectual and social circles. The debate and criticism mainly deals with dilemmas wheather with this agreement is exceeded Ahtisaari Plan, or with this Agreement we have Ahtisaari plus. According to the agreement approved by the Assembly of Kosovo, we see that the Ahtisaari Plan is not exceeded, and all points contained in the Agreement and reached solutions are within the legal and constitutional system of Kosovo.

The agreement as a whole has 14 points and those points that reflect the areas of responsibility for the municipalities of this agreement are:

1. It will be an Association / Union of Serb-majority municipalities in Kosovo. Membership in it will be open to other municipalities, which are mentioned in the agreement.

2. The union / association will be established by the statute. Its distribution will occur only by a decision of the parties involved. Legal guarantees will be insured by the law in power and constitutional law (including 2/3 of majority from the decision-making body).

3. The structures of the Association / Union will be established on the same basis as the existing statute of the Association of Kosovo Municipalities, for example, the chairman, deputy chairman, Assembly, Council.

4. In accordance with the given competences by the European Charter of Local Self-Government and Kosovo Law, the participating municipalities will have the right to cooperate in exercising their collective powers through the Union / Association. The Association / Union will have full access in the areas of economic development, education, health, urban and rural planning.

5. The Association / Union will also carry additional liability, depending on how they are delegated by the central authorities.

6. The Community / Union will have a role of representation for the central authorities and because of this purpose they will have a seat on the community consultant council. In accordance with this, it is foreseen a monitoring function.

7. There would be a Regional Police Commander for four Serb-majority municipalities (North Mitrovica, Zvecan, Zubin Potok and Leposavic). A commander of this region will be a Kosovo Serb, nominated by the Ministry of Interior, from a list that will be provided by four mayors.

8. Municipal elections in northern municipalities will be organized in 2013 , with the assistance of OSCE, in 
accordance with Kosovo law and international standards.

\section{References}

Decree on Local Government, August 1999, the Kosovo Provisional Government UNMIK Regulation 2000/43,

UNMIK Regulation No. 2000/45

Constitutional framework (UNMIK Regulation No. 2001/9)

UMNIIK Regulation No. 2007/30,

Comprehensive Plan of the president Ahtisaari, September 2007

Law on Local Self-Government in the Republic of Kosovo, 2008

Law on municipal administrative boundaries, 2008

Law for Municipal finances, 2008

The Law on Public Financial Management and Accountability, 2008

The Constitution of the Republic of Kosovo, 2008

Brussels Agreement between Kosovo and Serbia, 19 April 2013 
